\title{
«В Танну-Туву». Об одной полузабытой книге
}

\author{
Маргарита П. Татаринцева \\ Тувинский институт гуманитарных и прикладных социально-экономических исследований \\ при Правительстве Республики Тыва, Российская Федерация
}

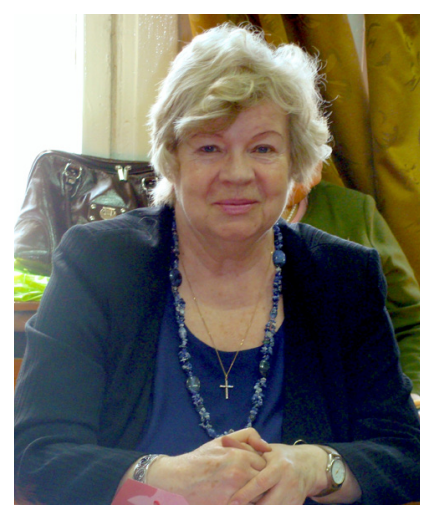

В статье анализируется книга В. Мачавариани и С. Третьякова «В Танну-Туву», выходившая в 1930 и 1931 гг. в жанре трэвел - по следам поездки В. Мачавариани, деятеля Коммунистического Интернационала Молодежи, в Туву. Учитывая то, что книг о Туве времен Тувинской Народной Республики крайне мало, особенно рассчитанных на широкого читателя, в статье обосновывается ее ценность и для науки, и для обычного читателя.

Дается краткая история издания, в том числе почему у автора книги В. Мачавариани появился соавтор - писатель С. Третьяков. Сам В. Мачавариани выполнял в Туве серьезнейшую миссию - укреплял роль комсомола, встречался с руководящим составом партии и госаппарата молодой республики. Тем не менее основным содержанием книги стали не общественно-политические события и начавшиеся перемены в быту тувинцев, а необычные впечатления от окружающего мира с определенной долей юмора. Здесь и природа, и поселения, и люди, встречи и общения, разговоры и деловые заседания - все дано сквозь призму субъективного, личностного отношения автора. Книга получилась не общественно-политической, пропагандистской, а книгой-путешествием. Несмотря на свою занимательность, она была раскритикована и предана забвению.

Автор статьи рекомендует ее к переизданию с комментариями историков.

Ключевые слова: Тува; история Тувы; «В Танну-Туву»; В. Мачавариани; С. Третьяков; Усинский тракт; Кызыл; тувинцы

\section{Для цитирования:}

Татаринцева М. П. «В Танну-Туву». Об одной полузабытой книге // Новые исследования Тувы. 2020, № 3. C. 128-137. DOI: https://www.doi.org/10.25178/nit.2020.3.9

Татаринцева Маргарита Петровна - кандидат филологических наук, ведущий научный сотрудник сектора культуры Тувинского института гуманитарных и прикладных исследований при Правительстве Республики Тыва. Адрес: 667000, Россия, г. Кызыл, ул. Кочетова, д. 4. Тел.: +7 (394-22) 2-39-36. Эл. адрес: margotatar@mail.ru

TATARINTSEVA, Margarita Petrovna, Candidate of Philology, Leading Research Fellow, Sector of Culture, Tuvan Institute of Humanities and Applied Social and Economic Research under the Government of the Republic of Tuva. Postal address: 4 Kochetov St., 667000 Kyzyl, Russian Federation. Tel.: +7 (394-22) 2-39-36. Эл. адрес: margotatar@mail.ru

ORCID ID: 0000-0002-2118-1926 


\title{
“To Tannu Tuva": On a half-forgotten book
}

\author{
Margarita P. Tatarintseva \\ Tuvan Institute of Humanities and Applied Social and Economic Research \\ under the Government of the Republic of Tuva, Russian Federation
}

\begin{abstract}
The article analyses the book by V. Machavariani and S. Tretyakov titled 'To the Tannu Tuva', published in 1930-1931 in the genre of a travelogue, following the Tuvan trip of V. Machavariani, an official at the Communist Youth International. The book is important both for researchers and general readers, considering the lack of books about Tuva during the period of Tuvan People's Republic, especially written for the wide audience.

The article provides a brief history of the edition, including the fact why V. Machavariani had a co-author, writer S. Tretyakov. Machavariani carried out a serious mission in Tuva, strengthening the role of the Komsomol, meeting with the leadership of the party and the government of the young Republic. However, the book contained mostly his impressions of the world he saw in Tuva rather than sociopolitical events and grand changes in the life of Tuvans. The author describes nature, settlements, people, meetings and communications, conversations, and business meetings through the prism of his personal attitude. The book turned out to be a travel journal, and not a piece of socio-political propaganda as it might have been intended. Despite its entertaining content, it faced scathing criticism and was soon forgotten.

The author believes this book must be republished with historians' comments.
\end{abstract}

Keywords: Tuva; Tuvan history; “To Tannu Tuva”; V. Machavariani; S. Tretyakov; Usinsky trakt; Kyzyl; Tuvans

\section{For citation:}

Tatarintseva M. P. "V Tannu-Tuvu". Ob odnoi poluzabytoi knige ["To Tannu Tuva": On a half-forgotten book]. New Research of Tuva, 2020, no. 3, pp. 128-137. (In Russ.). DOI: https://www.doi.org/10.25178/nit.2020.3.9

\section{Введение}

Книга В. Мачавариани и С. Третьякова «В Танну-Туву» выходила девяносто лет назад в серии «Библиотека экспедиций и путешествий» дважды (Мачавариани, Третьяков, 1930, 1931) и нельзя сказать, что она совсем забылась, исчезла бесследно в глубине прошедшего времени, хотя стала малодоступной, редкой. У современного читателя она до сих пор может вызывать интерес и даже некоторое удивление живостью и непосредственностью изложения. Однако она не попадает в ряд широко цитируемых источников, хотя в библиографических списках ученых-исследователей обычно присутствует.

При тщательном изучении небольшой по объему книги В. Мачавариани и С. Третьякова (1-го издания 1930-го года, вышедшего тиражом 5100 экз.) выявляется одна ее особенность: ее не следует относить к строго научному историческому, общественно-политическому или публицистическому жанру, хотя в ней есть и эти составляющие - создана она была на документальной основе. Это рассказ о реальной поездке в Туву в конкретное время - в конце 1920-х гг. и вымышленных действующих лиц в ней нет.

В год 100-летнего юбилея Тувинской Народной Республики (ТНР) автору статьи хотелось обратиться к книге, относящейся именно к этому времени, изданной по горячим следам пребывания в ней ее автора - В. Мачавариани. Назрела необходимость в свете сегодняшнего дня раскрыть ее содержание, охарактеризовать автора и его соавтора, их цель создания книги, охарактеризовать особенности ее жанра, а также причины «забвения», замалчивания на долгие годы. По мнению автора статьи, книгу, которая стала библиографической редкостью, следует вернуть и в научный оборот, и широкому читателю. 


\section{Владимир Мачавариани}

Разобраться с особенностями жанра поможет не совсем обычная история создания книги.

У книги два автора - Владимир Мачавариани и Сергей Третьяков. Но зимой 1928-1929 гг. в Туве побывал только В. Мачавариани (годы жизни не известны), посланник Коммунистического Интернационала Молодежи (КИМ), комсомольский работник, а для несведующих - просто молодой грузин, который был командирован из Москвы в далекую Туву на IV съезд тувинской революционной молодежи - Ревсомола (Моллеров, 2016).

В трудах историков, изучающих этот период ТНР, в частности в «Истории Тувы» (История Тувы, 2007: 126-183) да и в самой небольшой по объему книжке хорошо отражены внутриполитические, экономические, международные трудности и сложности, которые переживало молодое тувинское государство, ставшее на путь некапиталистического развития, до этого находившегося на стадии феодализма. Отсутствие опыта руководящей работы у государственных начальников, почти полная неграмотность, внутренняя борьба за власть разных группировок, засилье прежних административных порядков, прежней элиты и авторитетов во всех сферах жизни, в том числе лам, шаманов, необходимость выстраивания новых взаимоотношений между простыми аратами и бывшими властителями, бедным населением и торговцами, тувинцами и русскими, несправедливое налогообложение - с таким обилием проблем столкнулся комсомольский посланец. Он хорошо отдавал себе отчет, сколько времени и сил потребуется обществу для разрешения хотя бы важнейших из проблем, чтобы могли начаться реальные преобразования. Это четко просматривается в его отчетах в Москву (например, отчет «Положение в Тувинской республике»: РГАСПИ, ф. 495, оп. 153, д. 35). Но не только это произвело впечатление на автора и отразилось в его книге.

Преодолев за двадцать дней зимний путь по железной дороге от Москвы до Абакана, а затем девятидневный путь от Минусинска по еще недостроенному Усинскому тракту до Кызыла, молодой грузин приобрел бесценный для него опыт по освоению бескрайнего пространства Сибири и знакомству с совершенно разными типами людей - извозчиками, золотодобытчиками, строителями, охотниками, мараловодами, ламами, цириками и т. д. Здесь все другое. Еще недавно Москва уроженцу Тифлиса казалась холодным городом, а когда он написал в письме отцу, что едет в Сибирь, тот со страхом спросил его: «За что тебя ссылают?» По мнению грузин, в Сибири жить нельзя, можно лишь отбывать наказание.

Описание пути-дороги в Туву довольно занимательно и по объему составляет более трети книги.

Итак, главный герой по служебной надобности должен был зимой пересечь почти всю страну, чтобы оказаться в мало кому известной, новой на карте мира республике Танну-Туве. Да и сам-то он узнал о ней совсем недавно, прочитав перед отъездом несколько случайно попавшихся на эту тему статей.

К сожалению, никаких конкретных данных о личности В. Мачавариани, кроме как из самой книги, найти не удалось, как и о его дальнейшей судьбе, в литературном творчестве он себя больше никак не проявил. Видимо, такими данными он и не обладал, но вот рассказать о своей необычной поездке в устной форме ему удалось так, что этот рассказ весьма впечатлил известного литератора, востоковеда, поэта, писателя и сценариста Сергея Михайловича Третьякова.

\section{От эмоционального рассказа - к познавательной книге}

Сергей Третьяков (1892-1939), известный литератор, сотрудничал с В. Маяковским и С. Мейерхольдом. У него уже было имя в литературных кругах, было напечатано несколько произведений на восточную тему, поскольку он бывал в Монголии, несколько лет преподавал русский язык и литературу в Китае, т. е. темой Востока интересовался живо и постоянно. (К сожалению, в 1939 г. С. Третьяков был репрессирован, в 1956 г. посмертно реабилитирован (Чертков, 1972: 614)).

Увлеченный эмоциональным рассказом В. Мачавариани о поездке в Туву С. Третьяков сразу же предложил издать его в виде книги-брошюры, однако тот сначала отказался от этой идеи наотрез, ссылаясь на отсутствие опыта и способностей к литературному творчеству. Хотя во время пребывания в командировке он вел дневник и посылал регулярные, подробные отчеты о своих действиях и наблюдениях в Москву, так что документальная основа его рассказа была в полном порядке и сомнению не подвергалась. 
Пришлось опытному С. Третьякову самому структурировать рассказ В. Мачавариани. Причем, акцент был сделан не на политическое и экономическое положение в республике, которые требовали очень серьезного анализа, а на удивительные, ни на что не похожие особенности этого дальнего края, дикой первозданной природы, образа жизни, обычаев небольшого, но жизнестойкого народа, который начинает новую жизнь и т. д. То есть, с самого начала книгу предполагалось сделать доступной рядовому читателю и интересной за счет неизвестных ему ранее фактов и подробностей - географических, исторических, этнографических и др.

Сам С. Третьяков в начале книги, вместо предисловия, под заголовком «Для ясности» написал:

«Рассказ тов. Мачавариани, ездившего на съезд ревсомола в Танну-Тувинскую республику, был настолько интересен, в этом повествовании было так много людей, выглядевших по-живому... что я немедленно предложил тов. Мачавариани записать свое путешествие и выпустить книжкою. Мачавариани испугался, отказался и выяснилось, что сделать книжку не так-то просто. Тогда эту книгу мы стали делать вдвоем.

Делали ее так: я расспрашивал тов. Мачавариани о поездке, а стенографистка этот рассказ нам записывала. Когда рассказчик впадал в разнообразие или схематизм, я начинал докапываться у него интересных и существенных деталей. Так, перекликаясь, сделали мы стенограмму книги. Сначала предполагали ее просто обработать и издать стено-

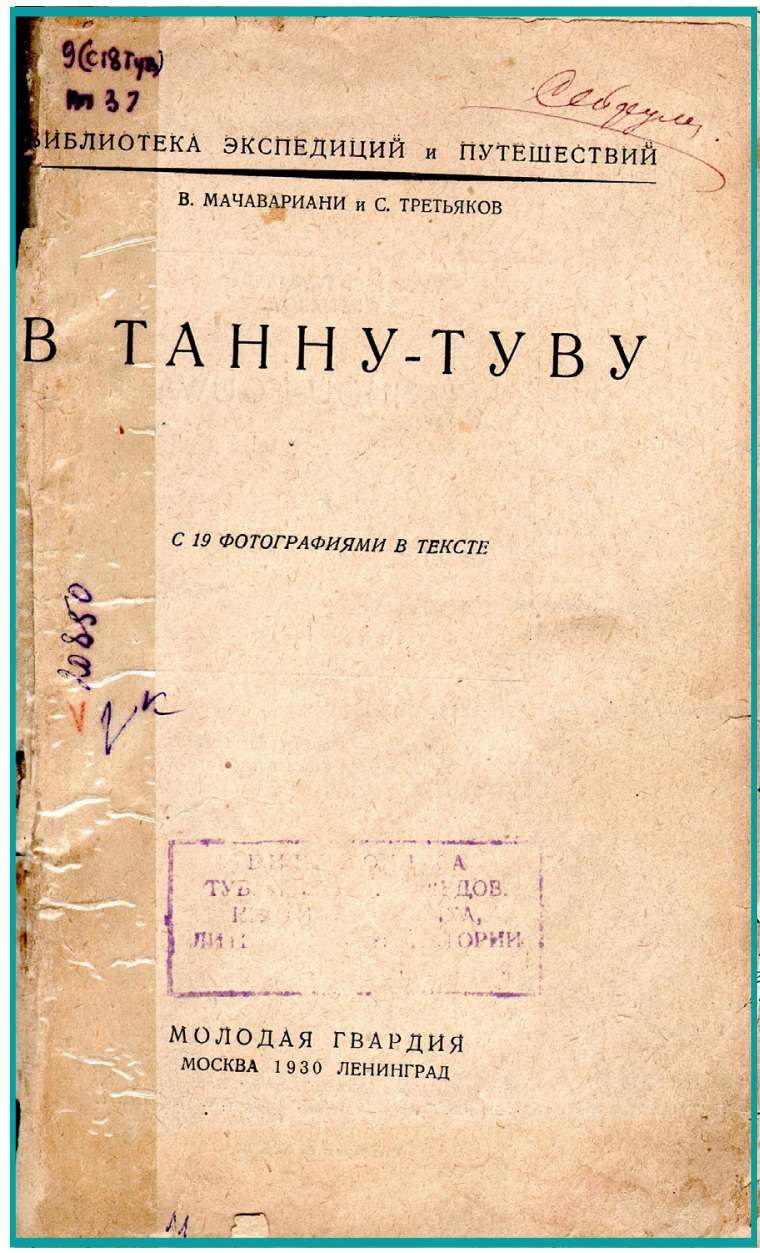

Фото 1. Титульный лист издания 1930 г. Photo 1. Title page of the 1930 edition. граммой же. Но это оказалось трудно, бессвязно..., поэтому над стенограммой была проделана следующая работа. Во-первых, все материалы были смонтированы, т. е. расчленены, а затем вновь расположены в определенном повествовательном порядке. Во-вторых, был выправлен язык изложения. В-третьих, был внесен целый ряд пояснительных и цифровых данных, взятых частью из отчетов того же тов. Мачавариани, затем тов. Нацова, добытых из бесед с некоторыми тувинцами и, наконец, основанных на моих личных впечатлениях о Монголии» (Мачавариани, Третьяков, 1930: 3-4).

Маститому литератору С. Третьякову удалось выстроить разностильный и разнохарактерный материал о поездке по бескрайней Сибири в Туву так, чтобы интерес читателя не ослабевал, а нарастал, фотографии же, правда, по сегодняшним меркам довольно тусклые, этот интерес подогревали. Все события, наблюдения, происшествия, впечатления о них были разбиты на небольшие главки: «Двадцать дней пути», «Через Саяны», «Откуда Тува», «Кызылские улицы», «Ламы», «Люди», «Съезд ревсомола» и др.

Как уже говорилось, целью поездки в Туву В. Мачавариани, посланца КИМа, были организация и участие в работе IV съезда тувинского ревсомола. Современные историки, хорошо знакомые с архивными материалами, указывают, что одной из задач его поездки была «сбросить правых», что, в общем, и удалось (Моллеров, 2013: 33-34).

Судя по интенсивной деятельности, встречам, заседаниям и совещаниям, на которых он участвовал и которыми руководил, его знакомство с общеполитической обстановкой и разными сторонами обновляющейся жизни было отнюдь не поверхностными, и поездка дала свои политические результаты. А ведь в самом начале Тува для него была в прямом смысле terra incognita. 
На первых страницах книги мы читаем:

«В первый раз я увидел тувинца на V Конгрессе КИМа. Шли прения по монгольскому вопросу. Человек, видимо, никогда не говорил в такой большой аудитории. Он был растерян и часто сморкался. Ему легче было ездить верхом, чем говорить в Колонном зале Дома Союзов. Он был в зимнем обмундировании военного образца. Дело было в августе. Но у неуклюжего человека была стремительная речь. Поддерживая КИМ, он атаковал делегата Монгольского национально-революционного союза молодежи» (Мачавариани, Третьяков, 1930: 5).

Отметим для себя объективность описания и добрую иронию автора. Такое сочетание в книге будет встречаться постоянно.

\section{Выбор жанра - трэвел}

В Российском государственном архиве социально-политической истории сохранились подробные отчеты о собственной работе В. Мачавариани в Туве и его наблюдения над политической жизнью молодого государства, провозглашенного в 1921 г. (РГАСПИ, ф. 495, оп. 153, д. 35, лл. 1-5.)

В них имеются характеристики многих общественных деятелей республики, имена которых остались в истории Тувы, но есть и те, что надолго были из нее вычеркнуты в результате чисток и репрессий, которые происходили в Туве по образцу СССР. По заметкам В. Мачавариани можно судить, какое огромное влияние оказывал опыт СССР на молодое государство, особенно в кадровой политике, что ценно для историка и политолога. Например, на них опирается Н. М. Моллеров в анализе политических событий в Туве конца 1920-х гг. (Моллеров, 2013). И. В. Отрощенко ссылается на наблюдения автора в анализе культурной политики периода ТНР (Отрощенко, 2015: 20-21). 3. Ю. Доржу и Р. О Шыырап приводят его описания при анализе социально-бытовых условий жизни кызылчан 1920-е гг. (Доржу, Шыырап, 2019: 649). М. С. Байыр-оол цитирует впечатления В. Мачавариани в 1928 г. от встречи с Буяном-Бадыргы, который был его оппонентом и сегодня признан одним из основателей тувинской государственности (Байыр-оол, 2011: 43). Заметки автора оказались даже любопытными для анализа истории похоронной обрядности тувинцев (Кисель, 2009: 17).

Но для массового читателя того времени, на которого ориентировались авторы «В Танну-Туву», такие исторические подробности осложнили бы чтение, сделали бы книгу труднодоступной. Да и дальнейшая судьба многих руководящих деятелей того времени прояснилась значительно позже, многие имена просто были вымараны из истории Тувы. Поэтому авторы пошли по другому пути - они попытались сделать книгу-путешествие в неведомую для многих страну в жанре, приближающемуся к жанру «трэвел» (от англ. trevel - путешествие) в современном литературоведении означающему журналистское путешествие ${ }^{1}$. Напомню, что она и вышла в серии «Библиотека экспедиций и путешествий».

Повествование в подобном жанре обычно опирается на документальную основу, конкретные исторические реалии, но окрашено личностью автора-рассказчика. Это его взгляд на все происходящее, поэтому используются и эмоциональные краски, могут быть такие вкрапления, как пейзажи, размышления, письма, попутные замечания, описания неожиданных происшествий и своя реакция на них и т. д.

Все это мы видим в нашей книге.

\section{Какие разные люди, какая удивительная страна}

В повествовании В. Мачавариани много места уделено его общению и с руководящей верхушкой ТНР, и с обычными гражданами этого края, местными работниками советских учреждений, и с дорожными попутчиками во время долгого пути. Поэтому здесь много картинок повседневной жизни этих людей, молодых и старых, разговоров с ними, рассказов об особенностях обычаев, поведения местного населения, привычках этих людей, их словечках, а также интересных этнографических деталей, портретных характеристик, описаний традиционной одежды, предметов быта, обычаев, каких больше нигде не встретишь. Таких занимательных и познавательных эпизодов, встреч, зарисовок немало в этой небольшой книжке.

${ }^{1}$ В современном литературоведении он стал обсуждаться в написании «травелог», см.: Аксенова, 2018; Пищаев, 2018. 


Novye issledovanila Tuny

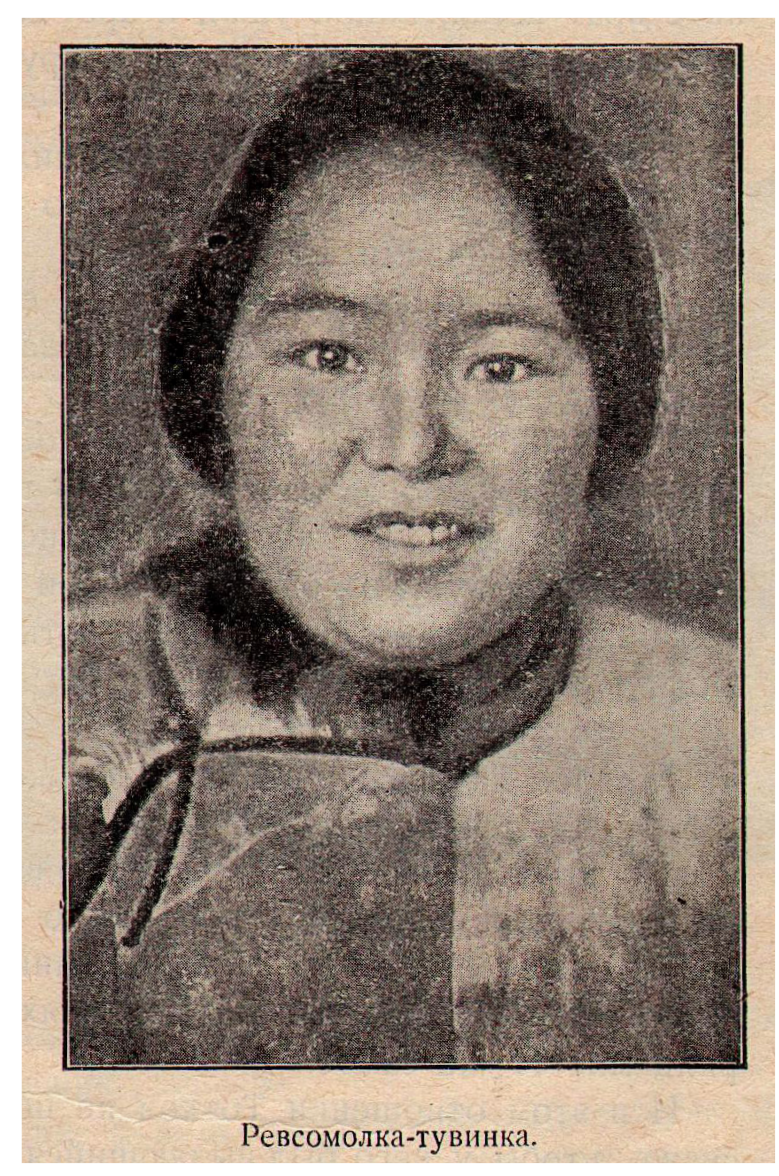

Фото 2. Фотография ревсомолки-тувинки со стр. 79 издания 1930 г.

Photo 2. Photo of a young Tuvan girl, member of the Revolutionary Youth Union, p.79, 1930 edition.

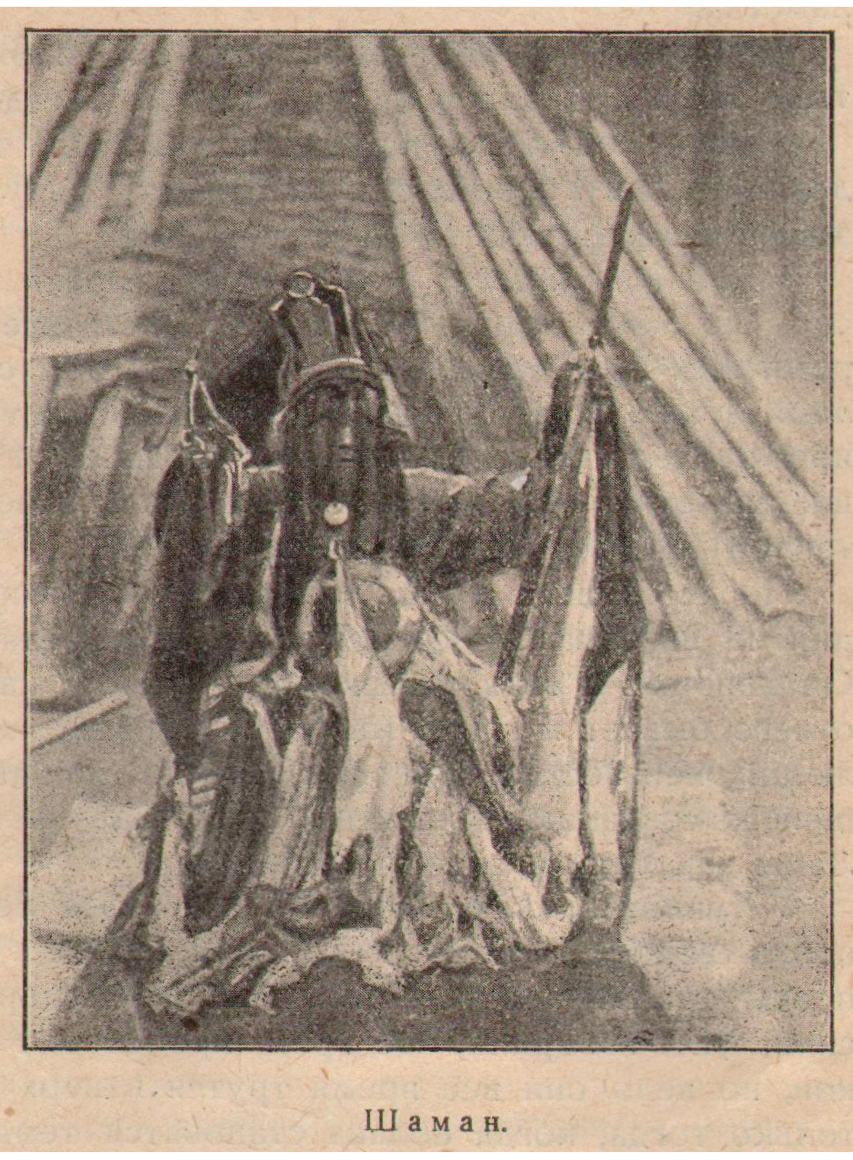

Фото 3. Фотография шамана со стр. 89 издания 1930 г.

Photo 3. Photo of a shaman, p. 89, 1930 edition.

Так, запоминается колоритный образ извозчика татарина Исламова, у которого профессионализму и ответственности за свое дело неплохо бы поучиться многим нашим современникам. Не только на собраниях, но и в непринужденной, а иногда и в бытовой обстановке В. Мачавариани общается с Буяном Бадыргы, Нацовым, Соднамом, Шыгдыржапом, Сатом Чурмит-Тажи, образованным ламой Севеном, Хемчиг-оолом, Мунией, Дондуком и другими деятелями, имена которых остались в истории ТНР. Он принимает их у себя, обедает с ними, бывает у них дома.

Интересно читать, как выглядела тогда столица Тувы Кызыл, основанная в 1914 г., которая показалась Мачавариани «бедной деревушкой», в которой проживало всего-то полторы тысячи жителей, как были устроены в ней жилища - избы и юрты, во что были одеты-обуты начальники и простой народ, как люди вели себя в общественных местах и учились выступать на собраниях, как смотрели кино - диковинку того времени и т. д. Автору любопытно, какими методами лечат местных жителей ламы и шаманы, как в Туве хоронят покойников, как традиционно рожают тувинские женщины и многое другое, необычное, чего больше не увидишь нигде. Ни один автор-путешественник не пройдет мимо таких фактов. Да и бытовые сценки, например, рассказы о своенравном козле, который стал достоянием и грозой всего города, тоже занимательны (Мачавариани, Третьяков, 1930: 96).

Так, на одних страницах автор резко высказывается о несправедливом налогообложении, при котором бедные беднеют, а богатые богатеют - это буквальные слова Чурмит-Тажи, сказанные в беседе с В. Мачавариани 28 декабря 1928 г. (см.: РГАСПИ, ф. 533, оп. 8, д. 120, л. 4; Мачавариани, Третьяков, 1930: 55), о распространенных среди населения опасных болезнях, с которыми бороться еще не хватает врачей (туберкулез, сифилис). А через несколько страничек мы читаем про уморительные похождения ничейного козла (там же: 95-96). 
Касается автор и вопросов гигиены, не только наблюдая жизнь местных жителей Тувы - как русских, так и тувинцев, но и обращая внимание на отношение к этим вопросам и других своих знакомыхпопутчиков по долгой дороге из Москвы в Туву. Вызывает улыбку, например, эпизод, рассказывающий о принципиальной разнице во взглядах у некоторых людей на приоритеты в профессиональных обязанностях. Так, В. Мачавариани настойчиво просил проводника вагона, в котором он ехал, навести в нем порядок, хотя бы вывести клопов, ведь в вагоне едут и иностранцы. Но проводник отмахивался от его просьб, заявляя, что первым делом ему нужно в вагоне оформить ленинский уголок. Знакомая картинка!

Жанровая свобода трэвел приводит к синкретичности повествования - сплетению пейзажно-лирических отступлений с публицистичностью, воспоминаниями, этнографических зарисовок с портретными характеристиками. Причем в повествовании на всем протяжении четко просматривается субъективизм автора: этот мир мы видим его глазами, через его личностное восприятие. В. Мачавариани, рассказчика, мы воспринимаем как общительного, толерантного, терпеливого человека, не лишенного чувства юмора и способности удивляться. Исследователь жанра Н. М. Маслова подчеркивает, что трэвел - «это описание мира через фильтр личного восприятия автора, мир, каким я его вижу» (Маслова, 1980: 6). Все эти особенности повествования могут создать ощущение непоследовательности, клочковатости, сумбурности в некоторых частях изложения, а также вызвать упрек в отсутствии четко выверенного взгляда на жизнь народа, никогда раньше не имевшего своей государственности.

В книге заметно отсутствие политического, идейного пафоса у профессионального работника идеологического фронта, хотя и совсем молодого, который обычно присутствовал в книгах такого рода других сочинителей. Может быть, не стоило автору обращать внимания на грязь и бытовую неустроенность, сифилис, слишком экзотические, даже диковатые обычаи и т. д., а обратить внимание в основном на передовые тенденции, воодушевление и подъем, с которым люди обсуждают на собраниях будущую справедливую и счастливую жизнь, их надежды и т. д.?

В. Мачавариани, как уже говорилось, в своих отчетах в Москву трезво и без иллюзий оценивал политическое и экономическое положение в Туве, верно понимал суть вещей, далекую от оптимизма ${ }^{1}$, но в книге все-таки выразил позитивную надежду: «Уже на второй день (пребывания в Кызыле. - M. $T$.) я убедился, что Кызыл хотя и деревушка, но политическая жизнь там кипит. Ни с каким Минусинском и Ачинском Кызыл нельзя сравнивать. Это действительно центр республики. Политический клубок сложен. Работают министерства, идет обсуждение различных вопросов, и это захватывает всех жителей Кызыла. Так рухнуло мое первое представление, что в Кызыле жить скучно» (Мачавариани, Третьяков, 1930: 53).

\section{Судьба книги «В Танну-Туву»}

Книга, как уже говорилось, была издана и в 1930 г. и переиздана сразу же в 1931 г., то есть интерес вызвала немалый.

Но, однако, сохранились и другие оценки, которые, возможно, повлияли на ее дальнейшую судьбу. Я имею в виду высказывание глубоко уважаемого и почитаемого всем тувинским народом ученого А. А. Пальмбаха, который в своем очерке «Века и годы» 1931 г., переизданного в сборнике 1967 г., довольно резко и нелицеприятно высказался так:

«Последний раз написали книгу о старой Туве Мачавариани и Третьяков. Она называется “В Туву”. Хотели увидеть новую Туву и ее не увидели. От снисходительных балагуров мир узнает о маленьком народе где-то на пупе Азии - в горном котле между Саянами и пустыней Гоби. Узнает о жестоком холоде, от которого губы музыкантов 1 тувинского оркестра примерзают к трубам, и о том, что единственный чистоплотный в стране человек - сын Хамбо-ламы.

Досужие люди пишут с птичьего полета о прогулках в Туву. Пусть пишут и пусть смеются над своей Тувой в ламском клобуке. Её нет!» (Пальмбах, 1967: 37).

Чувства А. А. Пальмбаха, которого задел насмешливый тон некоторых высказываний книги и субъективная интерпретация отдельных эпизодов, хорошо понятны. Сам он чуть позже, в начале 1930-х гг.

${ }^{1}$ Например, И. В. Отрощенко в исследовании вопросов вхождения Тувы в состав СССР ссылается на доклад В. Мачавариани заместителю заведующего Восточным секретариатов Исполкома КИМ П. Мифа о геополитических вопросах того времени (Отрощенко, 2017: 58-59). 
активно внедрял в культуру Тувы только что разработанную с помощью советских тюркологов под руководством Н. Н. Поппе национальную письменность, был увлечен и воодушевлен успехами в этой области, выступал перед жителями самых разных уголков Тувы. Он знал тувинский язык, радовался появлениям первых печатных изданий, букварей на нем, а также приветствовал первые попытки будущих тувинских писателей сочинить что-либо свое на актуальные темы дня и т. д. Этой деятельности он отдавал столько сил и времени, что тувинские писатели несколько позже называли его «беспощадный к себе человек» (выражение О. Саган-оола) (Татаринцева, 2017: 63). Начало этой работы и первые шаги важнейших культурных преобразований в стране отразились в его очерках 1931 г. «Века и годы». По сути, в этих очерках изображена та же страна, те же люди и то же время, что и у В. Мачавариани и С. Третьякова, но только через призму начавшихся перемен, столь дорогих для Пальмбаха, в какой-то степени являвшихся делом его собственных рук. Отсюда понятна реакция на книгу о Туве, написанную совсем с другими целями и с других позиций, в другой тональности, книгу о путешествии в неведомую страну, в которой авторам важно было показать ее удивительную непохожесть, самобытность, своеобразие, пусть даже некую экзотику. Конечно, из книги Мачавариани и Третьякова видно, как старые порядки, старый быт медленно сдают свои позиции, но ни о каком особом снисходительном балагурстве, высмеивании, как считал Пальмбах, а тем более глумлении над маленьким народом, долгое время жившим почти в изоляции от большого мира, речи быть не может.

В книге, как мы считаем, этого нет. Напротив, авторы стараются показать не только удивительное и непривычное в жизни тувинцев с «европейской» точки зрения, но и лучшее, что присуще им по сравнению, скажем, с соседними народами. Например, отношение к женщине:

«В отличие от Китая, - пишут авторы, - где женщина считалась существом низшим и презренным, в Туве женщина в почете.... Чурмит Таш утверждал, что женщин в Туве никогда не били. Он говорил это очень искренно, и возможно, что он прав» (Мачавариани, Третьяков, 1930: 60).

Или пример непосредственного контакта с совершенно незнакомым тувинцем, который пришел на помощь в тот момент, когда В. Мачавариани неожиданно упал с лошади: «...меня поразила эта доброта, отзывчивость, ласковая и совсем детская» (там же: 93). Примеры можно продолжить.

Живое общение автора с новыми людьми, простодушное удивление необычному, иногда добрая ирония, доброжелательность в целом и множество ярких впечатлений - все это привело к тому, что впечатления были подхвачены писателем С. Третьяковым, который и сам «загорелся» от этого рассказа. Да, в книге можно встретить насмешливый тон и нет пропагандистского пафоса, но это скорее можно отнести к ее достоинствам, чем к недостаткам. Прямолинейным и неумеренным пафосом, идеологическим нажимом традиционно злоупотребляли советские литераторы, сильно идеализируя жизнь отсталых национальных окраин, и такие сочинения, скажем прямо, морально устаревали очень быстро и большого интереса у читателя не вызывали.

\section{Заключение}

В книге В. Мачавариани и С. Третьякова «В Танну-Туву» упомянуто немало подлинных исторических деятелей ТНР, которые были репрессированы. Именно поэтому долгое время переиздавать книгу с их именами не представлялось возможным. Да и один из авторов ее - С. Третьяков - также был репрессирован и надолго был вычеркнут из списков писателей. Вместе с нелестным отзывом А. А. Пальмбаха эти три фактора, пожалуй, и повлияли на судьбу книги - она оказалась полузабытой.

Сейчас все это осталось позади, справедливость восстановлена, а Тува конца 1920-х годов, описанная в книге В. Мачавариани и С. Третьякова легко, увлекательно, конкретно, встаёт как живая. Авторы не претендовали на строгую научную фиксацию фактов и долгую жизнь своей скромной книжки. Они хотели привлечь к Туве, почти неведомой читателю, внимание, вызвать интерес. И это им удалось.

На наш взгляд, эта книга не заслуживает забвения, ведь это своего рода документ эпохи, она интересна и познавательна. С некоторыми историческими комментариями ее полезно переиздать для нового поколения массового читателя.

\section{Благодарности}

Выражаю огромную благодарность доктору исторических наук Н. М. Моллерову за предоставленные архивные материалы о деятельности в Туве В. Мачавариани и исторические консультации по эпохе Тувинской Народной Республики. 


\section{СПИСОК ЛИТЕРАТУРЫ}

Аксенова, М. В. (2018) Травелог: путешествие жанра и жанр путешествий // Актуальные проблемы филологии и педагогической лингвистики. № 3. С. 170-176. DOI: https://www.doi.org/10.29025/2079-6021-2018-3(31)-170-176

Байыр-оол, М. С. (2011) Три столпа тувинской государственности [Электронный ресурс] // Новые исследования Тувы. № 2-3. С. 37-61. URL: https://nit.tuva.asia/nit/article/view/404 (дата обращения: 12.03.2020).

Доржу, 3. Ю., Ширап, Р. О. (2019) Социально-бытовые условия жизни населения г. Кызыла - столицы Тувинской автономной области (1944-1961) // Oriental Studies. № 4. C. 645-660. DOI: https://www.doi.org/10.22162/2619-09902019-44-4-645-660

История Тувы (2007) / под общ. ред. В.А. Ламина. Новосибирск : Наука. Т. 2. 428 с.

Кисель, В. А. (2010) Поездка за красной солью. Погребальные обряды Тувы. XVIII - начало XXI в. СПб. : Кунсткамера. 142 с.

Мачавариани, В., Третьяков, С. (1930) В Танну-Туву. М. ; Л. : Молодая гвардия. 116 с.

Мачавариани, В., Третьяков, С. (1931) В Танну-Туву : очерк с 18 фотографиями. 2-е изд. М. : Огиз Молодая гвардия. 108 с.

Маслова, Н. М. (1980) Путевой очерк. Проблемы жанра. М. : Знание. 64 с.

Моллеров, Н. М. (2013) О смене властной элиты и политического курса в конце 1920-х годов в связи с китайскими и монгольскими событиями // Вестник Тувинского государственного университета. Социальные и гуманитарные науки. Вып. 1. С. 24-36.

Моллеров, Н. М. (2016) Советские дипломаты и представители Коминтерна в Тувинской Народной Республике в 1920-е гг. // Новые исследования Тувы. № 3. С. 5-18. URL: http://nit.tuva.asia/nit/article/view/460 (дата обращения: 12.03.2020).

Отрощенко, И. В. (2015) Языковая политика и культурное строительство в Тувинской Народной Республике [Электронный ресурс] // Новые исследования Тувы. № 2. C. 16-31. URL: https://nit.tuva.asia/nit/article/view/22 (дата обращения: 12.03.2020).

Отрощенко, И. В. (2017) Вхождение Тувы в состав СССР: альтернативные мнения // Новые исследования Тувы. № 4. С. 36-76. DOI: https://www.doi.org/10.25178/nit.2017.4.3

Пальмбах, А. А. (1967) Века и годы // А. А. Пальмбах - писатель и человек / сост. М. А. Хадаханэ. Кызыл : Тувинское книжное издательство.179 с. С. 36-55.

Пищаев, А. Г. (2018) Травелог: к вопросу о жанре // Материалы И методы инновационных исследований и разработок : сборник статей Международной научно-практической конференции / отв. ред. А. А. Сукиасян. Уфа : ООО «Аэтерна». 219 с. С. $65-70$.

Татаринцева, М. П. (2017) Литературное творчество А. А. Пальмбаха // Русский язык в Туве. № 2. С. 62-64.

Чертков, Л. Н. (1972) Третьяков Сергей Михайлович // Краткая литературная энциклопедия : в 9 т. М. : Советская энциклопедия. Т. 7. «Советская Украина» - Флиаки / гл. ред. А. А. Сурков. 1008 ст. С. 614.

Дата поступления: 22.04.2020 г.

\section{REFERENCES}

Aksenova, M. V. (2018) Travelog: puteshestvie zhanra i zhanr puteshestvii [Travelogue: travelling of the genre and the genre of travelling]. Aktual'nye problemy filologii i pedagogicheskoi lingvistiki, no. 3, pp. 170-176. (In Russ.). DOI: https:// www.doi.org/10.29025/2079-6021-2018-3(31)-170-176

Baiyr-ool, M. S. (2011) Tri stolpa tuvinskoi gosudarstvennosti [The three pillars of Tuvan statehood]. New Research of Tuva, no. 2-3, pp. 37-61 [online] Available at: https://nit.tuva.asia/nit/article/view/404 (access date: 12.03.2020). (In Russ.).

Dorzhu, Z. Yu. and Shirap, R. O. (2019) Sotsial'no-bytovye usloviia zhizni naseleniia g. Kyzyla - stolitsy Tuvinskoi avtonomnoi oblasti (1944-1961) [Kyzyl - the Capital of Tuvan Autonomous Oblast (1944-1961): Social and Living Conditions of the Population]. Oriental Studies, no. 4, pp. 645-660. (In Russ.). DOI: https://www.doi.org/10.22162/26190990-2019-44-4-645-660

Istoriia Tuvy [The History Of Tuva] (2007): in 3 vols. / ed. by V. A. Lamin. Novosibirsk, Nauka. Vol. 2. 430 p. (In Russ.).

Kisel', V. A. (2010) Poezdka za krasnoi sol'iu. Pogrebal'nye obriady Tuvy. XVIII - nachalo XXI v. [A Journey for the red salt. Funeral rites of Tuva. XVIII - early XXI century]. St. Petersburg, Kunstkamera. 142 p. (In Russ.). 
Machavariani, V. and Tret'iakov, S. (1930) V Tannu-Tuvu [To Tannu-Tuva]. Moscow, Leningrad, Molodaia gvardiia. 116 p. (In Russ.).

Machavariani, V. and Tret'iakov, S. (1931) V Tannu-Tuvu [To Tannu-Tuva]: an essay with 18 photos. $2^{\text {nd }}$ ed. Moscow, Ogiz Molodaia gvardiia. 108 p. (In Russ.).

Maslova, N. M. (1980) Putevoi ocherk. Problemy zhanra [The travel essay. The problems of the genre]. Moscow, Znanie. 64 p. (In Russ.).

Mollerov, N. M. (2013) O smene vlastnoi elity i politicheskogo kursa v kontse 1920-kh godov v sviazi s kitaiskimi i mongol'skimi sobytiiami [On the change of the power elite and political course in the late 1920s in connection with the events in China and Mongolia]. Vestnik Tuvinskogo gosudarstvennogo universiteta. Sotsial'nye i gumanitarnye nauki, vol. 1, pp. 24-36. (In Russ.).

Mollerov, N. M. (2016) Sovetskie diplomaty i predstaviteli Kominterna v Tuvinskoi Narodnoi Respublike v 1920-e gg. [Soviet diplomats and Comintern representatives in People's Republic of Tuva in the 1920s]. New Research of Tuva, no. 3, pp. 5-18 [online] Available at: http://nit.tuva.asia/nit/article/view/460 (access date: 12.03.2020). (In Russ.).

Otroshchenko, I. V. (2015) Iazykovaia politika i kul'turnoe stroitel'stvo v Tuvinskoi Narodnoi Respublike [The language policy and culture building in the Tuvan People's Republic]. New Research of Tuva, no. 2, pp. 16-31 [online] Available at: https://nit.tuva.asia/nit/article/view/22 (access date:12.03.2020). (In Russ.).

Otroshchenko, I. V. (2017) Vkhozhdenie Tuvy v sostav SSSR: al'ternativnye mneniia [Tuva's Accession to the USSR: Alternative opinions]. New Research of Tuva, no. 4, pp. 36-76. (In Russ.). DOI: https://www.doi.org/10.25178/nit.2017.4.3

Pal'mbakh, A. A. (1967) Veka i gody [Centuries and years]. In: A. A. Pal' mbakh - uchenyi, pisatel', prosvetitel' : $k$ 100-letiiu so dnia rozhdeniia [A. A. Palmbakh: scientist, writer, educator: for the 100th anniversary of his birth]. Kyzyl, IPK «Ene sozu». 179 p. Pp. 36-55. (In Russ.).

Pishchaev, A. G. (2018) Travelog: k voprosu o zhanre [Travelogue: the question of genre]. In: Materialy I metody innovatsionnykh issledovanii $i$ razrabotok [Materials and methodologies of innovative research and development] : collection of articles of the International scientific and practical conference / ed. by A. A. Sukiasian. Ufa, OOO «Aeterna». 219 p. Pp. 65-70. (In Russ.).

Tatarintseva, M. P. (2017) Literaturnoe tvorchestvo A. A. Pal'mbakha [Literary works of A. A. Pal'mbakh]. Russkii iazyk $v$ Tuve, no. 2, pp. 62-64. (In Russ.).

Chertkov, L. N. (1972) Tret'iakov Sergei Mikhailovich. In: Kratkaia literaturnaia entsiklopediia [Concise literary encyclopedia] : in 9 vol. Moscow, Sovetskaia entsiklopediia. T. 7. «Sovetskaia Ukraina» - Fliaki / editor-in-chief A. A. Surkov. 1008 p. P. 614. (In Russ.).

Submission date: 22.04.2020. 